\title{
The Use of a Blended Learning Environment by Primary School Student Teachers to Study Music Theory
}

\section{Hietanen, Lenita}

2017-04-14

Hietanen , L \& Ruismäki , H 2017 , ' The Use of a Blended Learning Environment by Primary School Student Teachers to Study Music Theory ' , The European Journal of Social \& Behavioural Sciences , vol. 19 , no. 2 , 212 , pp. 2393-2404 . https://doi.org/10.15405/ejsbs.212

http://hdl.handle.net/10138/181077

https://doi.org/10.15405/ejsbs.212

cc_by_nc_nd

publishedVersion

Downloaded from Helda, University of Helsinki institutional repository.

This is an electronic reprint of the original article.

This reprint may differ from the original in pagination and typographic detail.

Please cite the original version. 


\title{
The European Journal of Social and Behavioural Sciences EJSBS
}

\section{The Use of a Blended Learning Environment by Primary School Student Teachers to Study Music Theory}

\author{
Lenita Hietanen $^{\mathrm{a}} *$, Heikki Ruismäki ${ }^{\mathrm{b}}$ \\ ${ }^{a}$ Univesity of Lapland, PO Box 122, 96101 Rovaniemi, Finland \\ ${ }^{b}$ University of Helsinki, P.O. Box 8, 00014 University of Helsinki, Finland
}

http://dx.doi.org/10.15405/ejsbs.212

\begin{abstract}
Music education, as part of general education in Finland, includes only a few compulsory courses. Primary school teachers are mainly responsible for music education during the first six school years. One big challenge arises from primary school student teachers' competences in music and confidence in teaching it. Many student teachers have studied only the compulsory music courses at the schools before their teacher training. However, in Finnish curricula for basic education, music is defined as a many-sided subject. Lecturers (the authors) in the Finnish teacher education system have noticed that, if the student teachers' knowledge is based only on the compulsory music courses, they find especially music theory difficult to understand. However, understanding the triad, for example, is essential for teachers to be able to instruct pupils in many-sided tasks. The purpose of the present study is to find out how student teachers study the music theory required of music teachers: in the current case, they are studying the triad. The learning environment organized by the main lecturer (one of the authors) is based on the principles of blended learning. Blended learning in the current study means exploiting contact lessons, students' autonomous or face-to-face learning periods, peer learning, and the e-learning possibilities. The main findings are that most of the students exploited the offered possibilities of the blended learning environment. However, although a blended learning approach offers more flexibility in responding to students' needs compared to traditional teaching-learning situations, it appears that students do not find each blended element useful.
\end{abstract}

* Corresponding author. Tel.: +0-000-000-0000 ; fax: +0-000-000-0000

E-mail address: lenita.hietanen@ulapland.fi

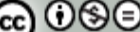

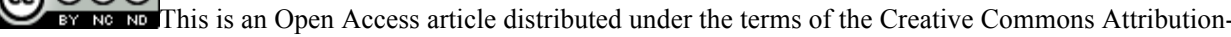
Noncommercial 4.0 Unported License, permitting all non-commercial use, distribution, and reproduction in any medium, provided the original work is properly cited. 


\section{Introduction}

Primary school teacher education in Finland takes place in universities, which means that the graduates obtain a master's degree in educational sciences. As defined in the Government Decree on University Degrees (Government Decree, 2004), Finnish primary school teacher education shall include multidisciplinary studies and cross-curricular themes. Music is one of the subjects for which primary school teachers are responsible during pupils' first six school years (Partanen et al., 2009). In the National Core Curriculum for Basic Education (The Finnish National Board of Education [FNBE], 2014), music as a subject can be considered a combination of the following approaches: singing, listening, playing instruments, composing, and connecting music with, for example, physical movement, pictures, and/or technology.

The multi-pronged approach to the subject in the curricula, creates challenges in teaching it, though the main activities during the music lessons are singing and playing instruments in a group. However, pupils' as well as student teachers' knowledge and skills in music often vary because some of them practice music as a hobby outside of school, too (Anttila, 2010; Partanen et al., 2009). On the other hand, many pupils and student teachers, who do not pursue music as a hobby, but instead have very low skills and knowledge in music. According to some previous studies, in addition to Finland, primary school student teachers' challenges focusing on their beliefs and confidence towards teaching music are acknowledged at least in Australia, England, and Italy as well (Biasutti et al., 2015; de Vries, 2013; Hallam et al., 2009; Holden \& Button; Seddon \& Biasutti, 2008). Hallam et al. (2009) and Thorn \& Brasche (2015) point out, that despite their low musical knowledge and skills, it is essential, that the primary school student teachers learn some kind of tools to teach music in the future. One of the main principles in basic education in Finland is that every pupil should be able to participate despite his/her previous skills or knowledge (FNBE, 2014). Therefore, every music teacher should be able to instruct their pupils in various tasks and offer them guidance in various phases of the tasks. In music, this requires teachers to also have a sufficient understanding of music theory.

Nonetheless, music theory is one aspect of general music education that has left many students with bad memories (Ruismäki \& Juvonen, 2011). Ruismäki and Tereska (2006) found that bad memories may interfere with music study even in adults in, for example, teacher education. Additionally, many students have not studied any music theory connected to practice (Ruismäki \& 
Juvonen, 2011). Without sufficient operational connection to music - including all the essential knowledge of and skills in the phenomenon - student teachers lack motivation in teaching and learning (Ruismäki, 1991; Ruismäki \& Ruokonen, 2009; Ruismäki \& Juvonen, 2011). The current investigation is based on the previous studies by suggesting that blended learning environment offers enough variations in learning methods to enable each primary school student teacher to study music theory based on practical music activities (Hietanen et al., 2016; Enbuska et al., 2016). According to Hallam et al. (2009), Ruismäki (1991), Ruismäki and Ruokonen (2009), Ruismäki and Juvonen (2011), and Seddon and Biasutti (2008), a motivated music teacher should have for example, an intensive operational relationship with music.

In current study, the theoretical parts of music as a phenomenon to be learnt are major and minor triads. The triad comprises three tones. The difference in pitch between the tones in the triad defines if it is major or minor triad. Based on the authors' more than 30 years' experiences as music lecturers, music teachers' understanding the triad offers quite an easy 'tool' with which to design various tasks, both in playing instruments and singing, for pupils in basic education with a range of musical skills and interests. The triad will be taught and learned through each student teacher's personal participation in music activities (Hallam et al., 2009; Ruismäki, 1991; Ruismäki \& Ruokonen, 2009; Ruismäki \& Juvonen, 2009; Seddon \& Biasutti, 2008), which refers to learning by doing (Elliott, 1995). Thus, in the examined intervention, we focus on the triads from a theoretical and practical view. The knowledge about the triads and skills, and competence in using them as a tool, are guided through the phases which are segmented into "reflected in and on action”. This, according to Schön (1987) occurs during the action (reflection-in-action) or after the action (reflection-on-action). To establish as flexible a learning environment as possible to support the students with various previous knowledge and skills in music, the learning environment was organized based on the principles of blended learning (Graham, 2006; Türel, 2016; Watson, 2008) combining various elements as follows:

* Lecturer-led situations

* Lecturer - student teacher -interaction

* Student teacher - student teacher -interaction

* Student teachers learning by doing

* Student teachers' (guided) autonomous learning: e-learning possibilities, learning through videos (Rockway), student teachers' common peer-learning and exploiting other music studies or previous achieved competence. 


\section{Problem Statement}

\subsection{Background}

Much of the research conducted in higher music education is focused on either music academies or conservatories (Partanen et al., 2009). These contexts vary from music teaching in primary school teacher education in several ways. First, the level of competence in music at the beginning of students' studies in conservatories and especially in academies is high: one must have a lot of experience with and skills in his/her instrument and/or singing to be accepted to study in such institutions. In contrast, in the aptitude tests for the primary school teacher education program, the students' musical skills are not tested at all. However, a lot of research on teaching music has been carried out among primary school student teachers, too (Hallam et al., 2009; Holden \& Button, 2006; Thorn \& Brasche, 2015). According to these findings, the student teachers seem to lack confidence in teaching music, which mainly is due to the lack of music skills and subject knowledge (Anttila, 2010; Hallam et al., 2009; Holden \& Button, 2006; Thorn \& Brasche, 2015). The studied compulsory music course is a part of primary school teacher studies. Music is compulsory in the student teachers' first year studies, but, after that, it is optional.

Based on the presented previous research and the practises of the authors as music lecturers during the past 30 years, the present study focuses on student teachers' study of the triad as an essential part of music theory that music teachers need to understand and exploit. Referring to the previous findings about the importance of learning by doing in studying music (Elliott, 1995; Hallam et al., 2009; Ruismäki, 1991; Ruismäki \& Ruokonen, 2009; Ruismäki and Juvonen, 2011; Seddon \& Biasutti, 2008), a learning environment based on the student teachers' intensive operational connection with music was designed.

\subsection{Purpose of the study}

We aim to reveal, through consideration of the case of triad study, the successes of and challenges met by primary school student teachers during music theory studies. The main purpose of the study is to discover the learning methods in the learning environment suitable for most students, regardless of their musical background. One purpose is to develop the learning environment by considering where and how the student teachers find the knowledge they need to complete the given task. This refers to the issue about how the learning environments in primary school teacher education should be developed in the future. In the current case, the researchers decided to use possibilities offered through the blended learning approach. 


\subsection{Research question}

Based on the previous researches and the authors' experiences as music lecturers and findings as scholars, the research question has been formulated as follows:

How do primary school student teachers search for and learn the needed knowledge, skills and competence in the blended learning environment in order to understand and use the triad as a tool in teaching music?

\section{Research Design}

\subsection{Methodological approach}

The methodological approach in this qualitative study is action research. The functions of action research are both to produce new knowledge about learning processes and to develop teachers' practices in enabling those processes (Elliott, 1998; Stenhouse, 1980). The present study involves experts in two Finnish universities who are developing music education teaching and learning environments (Manfra, 2009; Sagor, 2009). The experts are one professor, three university lecturers in music education and didactics, and one lecturer in music technology. In addition, a research assistant participated in several phases of the investigation by collecting the data, transcribing the video-recordings and diaries, and participating in the analysis among the experts.

In the current study, action research is understood as a practice-based research strategy (Carr, 2006). Normally, there are spirals of cycles typical for action research (Carr \& Kemmis, 1986). The current investigation focused mainly on two types of cycle. One cycle consists of the student teachers' various learning processes (the cycle of students' personal learning experiences and their increased knowledge, skills and competence in teaching music) through the entire program of music studies, whereby they study consecutive courses taught by several lecturers. The present study as a part of one of the compulsory music courses, comprises a small part of the student teachers' cycle. The other compulsory courses had for example piano and guitar studies, and practicing the music teaching situations, as topics. Another manifestation of a cycle arose from the discussions between the lecturers in the two universities and the research assistant concerning continuing circles of planning, reflections, and evaluations when the student teachers progressed in their studies during the academic year (the cycle of lecturers' increasing competence about the students' various ways to study and learn in the blended learning environment). 


\subsection{Participants and data collection}

The present study is one part of the research project carried out between the University of Helsinki and the University of Lapland during the academic year 2015-2016. The data in the present investigation, were gathered in one music course at the University of Lapland. There were 87 student teachers consisting the group of the first-year primary school student teachers at the university. In the beginning of the teacher-education programme, the student teachers were asked about their previous musical experiences and attitudes towards and confidence in teaching music through a questionnaire. The results of the questionnaire are presented in figure 1.

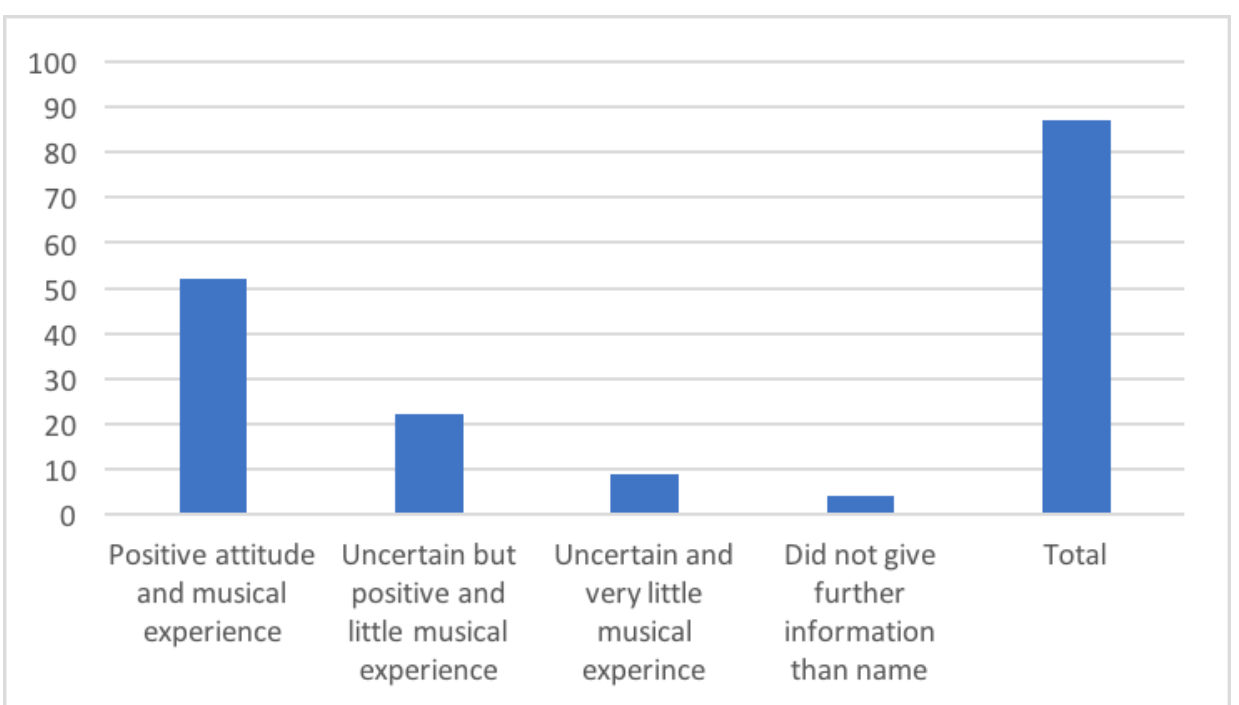

Figure 1. Student teachers' previous musical experiences and attitudes towards learning and teaching music before the music studies $(\mathrm{N}=87)$.

Before their music studies, 52 student teachers $(60 \%)$ manifested previous musical experiences and positive attitudes towards learning and teaching music. Twenty-two student teachers (25\%) manifested some previous musical experiences and showed uncertainty but clearly had positive attitudes towards learning and teaching music. Nine student teachers $(10 \%)$ had very little musical experiences and clear uncertainty. Four students $(5 \%)$ did not give any detailed information about these subjects. Later, in their musical activities and reflection diaries, it was confirmed that these four student teachers had hardly any understanding about music as a teachable and learnable subject. In conclusion, the results in the questionnaire confirm the previous findings (Holden \& Button, 2006), that there are huge variations between the primary school student teachers' knowledge, skills, competence in music and attitudes and confidence towards teaching music. 
The data in the present study were collected through reflection diaries, which written both during the studying process and at the end of it. This refers to "reflection in action and reflection on action", as defined by Schön (1987) as the way to formulate the knowledge from practical situations. There were 87 first-year student teachers, and 66 of them wrote in the reflection diaries by answering the following open questions:

1. What musical principles did you notice in the lecturer's accompaniment in the song A?

2. What kind of phases did you notice during the process of composing your accompaniment in the song B?

\subsection{Context}

In the investigated blended learning environment, the student teachers were offered many ways to study and exploit various ways to learn: identifying music knowledge and skills they had learned in informal or non-formal environments (Eshach, 2007; Werquin, 2008), using peer learning or studying in groups (Türel, 2016), using Rockway or the Internet in other ways (for example Google), and practicing according to their own schedule. The opportunities to study were applied according to the principles of blended learning, which combines e-learning, contact lessons, and different ways of studying and teaching and offers a wide range of possibilities, for example as observing relations between the student, lecturer, and e-learning platforms (Graham, 2006; Watson, 2008). As found out in some previous research (Hallam et al., 2009; Ruismäki \& Ruokonen, 2009; Seddon \& Biasutti, 2008), the student teachers' intensive operational connection with making music is essential when enhancing their knowledge, skills and confidence in teaching music in the future. Based on this, one of the main elements in the blended learning environment in the case was the student teachers' learning by doing.

The examined period started in the face-to-face lesson, when the students received a simple accompaniment pattern the lecturer had designed. First, they played the pattern in one song (song A) using xylophones during one music lesson. At the end of the lesson, the lecturer explained the students' next task: during their autonomous studying period, the student teachers needed to resolve the basis according to which the lecturer had chosen certain tunes for the accompaniment pattern in song A. Based on that solution, they were ordered to design their own accompaniments for another song (song B) to be played using xylophones. They were allowed to use the instruments in the practice rooms at the university if they wanted. 


\subsection{Analysis}

The student teachers' studying and learning process was designed to include problem solving about the tunes in the triads, using the triads creatively in composing the accompaniments, and reflecting on their learning both through these processes and immediately after the studying process. In their diaries, the student teachers explained what musical principles they recognized in the lecturer's accompaniment, how they progressed in their own accompaniment task based on the triads, the problems they encountered, where they sought help if needed, and if they used internet and/or Rockway.

The analysis was carried out through content analysis (Krippendorff, 2004), where the researchers sought descriptions about how the student teachers searched and used the needed knowledge in the offered blended learning environment.

\section{Findings}

Almost every student teacher identified the principles by which the lecturer had picked certain notes in the accompaniment pattern in song A and they were able to design their own pattern based on the same principles of using triads. However, three of the 66 student teachers were unable to complete this task. The three students wrote that during their autonomous period, they lacked sufficient musical skills and did not visit the practising rooms at the university to use instruments in the task. According to the student teachers' reflections, it seemed that they were close to identifying the principles but thought it was more complicated than it actually was and stopped trying. Referring to Hallam et al., (2009), Ruismäki and Ruokonen (2009) and Seddon and Biasutti (2008), during the autonomous studying period, the three students missed the essential operational connection with music, which seem to have been one reason for the students' failure in the task.

The student teachers came to understand the triad through face-to-face music lessons, Rockway videos, peer learning (peer students with more musical skills helped the others), using the Internet and testing the patterns on a piano/keyboard and/or as a result of previous musical experience and competence (Graham, 2006; Türel, 2016). 22 student teachers (33\%) solved the task using Rockway-videos or internet or both. 17 students (26\%) manifested to have made the task with a peer-learner. Eight student teachers (12\%) exploited the blended learning possibilities in the widest way, because they made the task with a peer-learner, and used Rockway-videos and internet. 31 students (47\%) did the task alone and without mentioning other ways to search the needed knowledge than their previous knowledge about music theory. In these figures, it is important to notice, that one student teacher may belong to several categories in the presented groups. 
The following responses reveal more insights on the student teachers' studying processes including their sources of the needed information:

I started to design my pattern to song B by getting familiar with the recommended videos in Rockway. Additionally, I used Internet a lot, for example by searching a virtual piano which helped me in the task without a real piano. (Student Teacher 23)

I found the recommended videos in Rockway useful with the task. They partly strengthened the knowledge I already had, but also increased it. The task was nice as I found experimenting various solutions by myself important in studying music. (Student Teacher 25)

First, I did not understand the task at all. Then I asked one of my peer learners with more musical skills help me to start. After that the task seemed to be quite easy: I managed the task and understood the idea in it. (Student Teacher 34)

The students noted their challenges as arising from several causes: the consideration that the task was too complicated, the absence of an instrument during the autonomous studying period, the lack of time due to the requirements of some other courses, and the lack of musical experience.

Based on the previous findings, and confirmed by the questionnaire responses used in the beginning of the teacher education programme, the primary school student teachers' musical backgrounds vary a lot, and in the beginning of their teacher education, many of the students have very low musical knowledge and skills and confidence towards teaching music (Anttila, 2010; de Vries, 2013; Hallam et al., 2009; Holden \& Button, 2006; Thorn \& Brasche, 2015).

The main purpose of the current study was to discover a suitable music learning environment offering ways to study and learn for most student teachers, regardless of their musical background. As the research question, we asked, how primary school student teachers search for and learn the needed knowledge, skills and competence in the blended learning environment in order to understand and use the triad as a tool in teaching music. When considering the student teachers' ways to seek the knowledge needed in the given task, close to half of the student teachers sampled (47\%) manifested that they had utilized the blended learning environment possibilities to some extent, including the e-learning possibilities (internet and/or Rockway -video lessons). However, about the same number of students did not appreciate the blended learning possibilities at all. They 
clearly seemed to have the needed knowledge and skills in music, but they did not describe, how and when they had achieved it.

\section{Conclusion}

As Ruismäki (1991) and Ruismäki and Juvonen (2011) found, the theoretical knowledge in music seems to be a challenge among the primary school student teachers, and needs to be connected to the practice in the studying process. In the current case, the investigation focusing on how the students study and learn, confirmed that learning by doing may support the contention that student teachers even with lower musical knowledge and skills need to understand theoretical details suitable as tools in teaching music. When referring to the flexibility of blended learning environment (Graham, 2006), the present study confirmed, that many of the student teachers did widely utilize the offered possibilities offered by the blended learning environment. However, essential that seemed to be, they were not required to use every blended option, but were able to make their own decisions about the necessary options that suited their learning needs. This was confirmed by the large number of the student teachers who did not mention the various possibilities in the blended learning environment at all, but managed to complete the task on their own. As used in current case, Graham (2006, p. 13) defines the way to organize the blends in the learning environment as enhancing or encouraging blends.

\section{Implications}

All in all, blended learning seems to offer a sufficient support to primary school student teachers with various music backgrounds and confidence in teaching music. In the present study, the group of experts from the two universities comprising the research group, carried out this action research in tight collaboration (Manfra, 2009; Sagor, 2009). The cycles of the lecturers' (the authors and other participating lecturers) increasing competence of student teachers' studying and learning processes in the blended learning environment responded to the definitions of the action research in teacher education (Elliott, 1998; Stenhouse, 1980). Additionally, the student teachers' cycles of the increasing knowledge and skills in music and competence in teaching music in the future seem to have strengthened in the current case. However, because there are many possibilities to select the blends in the learning environment (Graham, 2006), in the future, it should be worth of examining in more detail the blends the students use and how they used the blends. From this approach, the current study was an indicative one. It is hoped, that the findings encourage other teacher educators 
to research and design various blended learning environments to offer more flexibility to student teachers with various backgrounds in the subjects they are supposed to teach in the future.

\section{References}

Anttila, M. (2010). Problems with school music in Finland. British Journal of Music Education, 27(3), 241-253.

Biasutti, M. (2010). Investigating trainee music teachers' beliefs on musical abilities and learning: a quantitative study. Music Education Research, 12(1), 47-69.

Carr, W. (2006). Philosophy, methodology and action research. Journal of Philosophy of Education, 40(4), 421-435.

Carr, W. \& Kemmis, S. (1986). Becoming critical: education, knowledge and action research. London: Falmer Press.

deVries, P. (2015). Music without a music specialist: a primary school story. International journal of music education, 22(2), 210-221.

Elliott, J. (1998). The Curriculum Experiment. Meeting the challenge of social change. Buckingham: Open University Press.

Elliott, J. D. (1995). Music matters. A new philosophy of music education. New York, NY: Oxford University Press.

Enbuska, J., Hietanen, L. \& Tuisku, V. (2016). Dialogue Possibilities in Guided Autonomous Music Studies in Class-Teacher Education in Finland. Procedia - Social and Behavioral Sciences 217, 276-281.

Eshach, H. (2007). Bridging in-school and out-of-school learning: formal, non-formal and informal education. Journal of Science Education and Technology, 16(2), 171-190.

(The) Finnish National Board of Education [FNBE] (2014). National Core Curriculum for Basic Education 2014. Retrieved from http://www.oph.fi/ops2016/perusteet

Government Decree (2004). Government Degree on University Degrees 794/2004. Retrieved from http://www.finlex.fi/en/laki/kaannokset/2004/en20040794?search\%5Btype \%5D=pika\&search\% 5Bpika\%5D=794\%2F2004

Graham, C. R. (2006). Blended learning systems: Definitions, current trends, and future directions. In C. J. Bonk \& C. R. Graham (Eds.), The handbook of blended learning: Global perspectives, local designs (pp. 3-21). San Francisco, CA: Pfeiffer.

Hallam, S., Burnard, P., Robertson, A., Saleh, C., Davies, V., Rogers, L. \& Kokatsaki, D. (2009). Trainee primary-school teachers' perceptions of their effectiveness in teaching music. Music Education Research, 11(2), 221-240.

Hietanen, L., Ruokonen, I., Ruismäki, H. \& Enbuska, J. (2016). Student Teachers' Guided Autonomous Learning: Challenges and Possibilities in Music Education. Procedia - Social and Behavioral Sciences 217, 257-267.

Holden, H., \& Button, S. (2006). The teaching of music in the primary school by the non-music specialist. British Journal of Music Education, 23(1), 23-38.

Krippendorff, K. (2004). Content analysis. An introduction to its methodology. Thousand Oaks, CA: Sage. 
Manfra, M. M. (2009). Action research: Exploring the theoretical divide between practical and critical approaches. Journal of Curriculum and Instruction, 3(1), 32-46.

Partanen, P., Juvonen, A. \& Ruismäki, H. (2009). Finnish music education - structure and Lines. Arts-Contact Points Between Cultures. 1st International Journal of Intercultural Arts Education Conference: Post-Conference Book (eds. H. Ruismäki \& I. Ruokonen). Helsinki: University of Helsinki. Research Report 312, 15 -26.

Ruismäki, H. (1991). Musiikinopettajien työtyytyväisyys, ammatillinen minäkäsitys sekä uranvalinta. [Music teachers: Job satisfaction, professional self-concept and career choice]. Jyväskylä: Studies in the Arts 37. University of Jyväskylä.

Ruismäki, H. \& Juvonen, A. (2011). The good, the bad and the ugly memories from the school art subjects education. In Ruismäki, H. \& Juvonen, A. (eds.) Searching for a better life through Arts and Skills: Research results, visions and conclusions. Helsinki: University of Helsinki. Research report 329, 1-249.

Ruismäki, H. \& Ruokonen, I. (2009). Children's right to good music education - some practical applications and synthesis towards the ideals of the children's rights declaration. Problems in Music Pedagogy, 4-5, 7-17.

Ruismäki, H. \& Tereska, T. (2006). Early Childhood Musical Experiences: Contributing to PreService Elementary Teachers' Self-Concept in Music and Success in Music Education (during Student Age). European Early Childhood Education Research Journal, 14(1), 113-130.

Ruokonen, I. \& Ruismäki, H. (2016). E-learning in music: A case study of learning group composing in a blended learning environment. Procedia - Social and Behavioral Sciences, 217, $109-115$.

Sagor, R. (2009). Collaborative Action Research and School Improvement: We Can't Have one Without the Other. Journal of Curriculum and Instruction, 3(1), 7-14.

Schön, D. (1987). Educating the Reflective Practioner. London: Jossey-Bass.

Seddon, F. \& Biasutti, M. (2008). Non-music specialist trainee primary school teachers' confidence in teaching music in the classroom. Music Education Research, 10(3), 403-421.

Stenhouse, L. (1980). Reflections. In L. Stenhouse (Ed.) Curriculum Research and Development in Action. London: Heinemann Educational Books, 244-262.

Thorn, B., \& Brasche, I. (2015). Musical experience and confidence of pre-service primary teachers. Australian Journal of Music Education, 2, 191-203.

Türel, Y. K. (2016). Relationships between students' perceived team learning experiences, team performances, and social abilities in a blended course setting. Internet and Higher Education, $31,79-86$.

Watson, J. (2008). Blended learning: the convergence of online a face-to-face education. Promising practices in online learning. USA: North American Council for Online Learning.

Werguin, P. (2008). Recognition of non-formal and informal learning in OECD countries. A very good idea in jeopardy? Lifelong learning in Europe, 3, 142-149. 